\title{
Survival after Resection of a Primary Malignant Melanoma of the Small Intestine in a Young Patient: Report of a Case
}

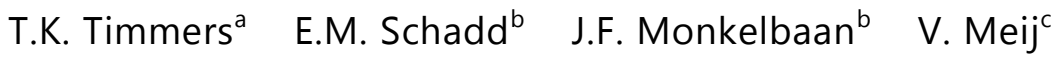 \\ ${ }^{a}$ Department of Surgery, University Medical Center Utrecht, and Departments of \\ ${ }^{b}$ Internal Medicine, Gastroenterology and Hepatology and 'Surgery, University Medical \\ Center Utrecht/Military Hospital Utrecht, Utrecht, The Netherlands
}

\section{Key Words}

Melanoma of the intestines $\cdot$ Malignant melanoma $\cdot$ Intestinal melanoma

\begin{abstract}
The occurrence of primary melanoma of the small intestine is rare. We describe the case of a 25-year-old man found to have a primary melanoma of the ileum. The patient presented with gradual onset of abdominal pain, fever, diarrhea, weight loss and fatigue. A preoperative diagnosis of a small intestinal tumor was based on the findings of computed tomography scanning. This diagnosis was confirmed at laparotomy and a partial small bowel resection was performed. Histopathological examination of the resected specimen clarified the exact nature of the lesion, confirming the diagnosis of melanoma. Thorough postoperative investigation did not reveal a primary lesion in the skin, gastrointestinal tract, oculus or brain. Thus, we diagnosed this tumor as a primary lesion. One year after his operation, the patient remains well without any evidence of recurrence. Thus, we diagnosed this small bowel tumor as a primary melanoma of the small intestine.
\end{abstract}

\section{Introduction}

Malignant melanoma is one of the most common neoplasms. However, primary noncutaneous melanoma is a rare entity and is most often described in ocular, mucosal and leptomeningeal sites [1]. Malignant melanoma is known to metastasize to the gastrointestinal (GI) tract [2]. Malignant melanomas account for 1-3\% of all malignant tumors of the GI tract $[3,4]$. The majority of these tumors are secondary lesions representing metastatic 
spread of a primary tumor [1]. Primary intestinal malignant melanoma has also been reported. However, the presence of primary malignant melanoma in the GI tract other than the esophagus and rectum, where melanocytes normally exist, is still controversial [4-7]. Distinguishing between a primary mucosal melanoma and a metastatic melanoma to the GI tract from an unknown or regressed cutaneous primary melanoma can be difficult. A potential metastatic nature remains hard to be formally excluded because they can precede the identification of a primary site that regresses spontaneously or is too small to be identified by conventional clinical and laboratory investigations $[4,8]$.

From a clinical point of view, both primary mucosal malignant melanoma and metastatic malignant melanoma are more aggressive than their cutaneous counterparts and have a worse prognosis. Median survival for those patients is 4-6 months. The relatively high 5 -year survival rate is $10 \%[1,5]$. Regardless of the exact origin of the melanotic lesion of the GI tract, the treatment of choice should be a curative intent en block resection of the tumor with sufficient free margins and mesentery $[3,4]$. Surgery, if curative, has a relatively low morbidity and mortality and long-term disease-free survival [4, 7]. Herein, we report the very unusual case of a large primary malignant melanoma of the small bowel in a young patient.

\section{Case Report}

A 25-year-old Caucasian male was admitted in our hospital with gradual onset of abdominal pain, fever, diarrhea (without blood), marked weight loss and fatigue. He did not complain about dysphagia, nausea or vomiting. His past medical history was unremarkable, except for an episode with equal symptoms 1 year before which was treated by his general practitioner with antibiotics with good effect on the symptoms. His physical examination was normal except for local tenderness in the lower abdomen. His laboratory findings revealed anemia (hemoglobin $5.1 \mathrm{mmol} / \mathrm{l})$ and elevated leukocytes $\left(21.7 \times 10^{9} / \mathrm{l}\right)$ and CRP $(147 \mathrm{mg} / \mathrm{l})$. The patient was admitted with the differential diagnosis of colitis. Endoscopic examination of the colon and terminal ileum, however, showed no abnormalities. Subsequently an abdominal ultrasound was made, which revealed a smooth-bordered circular mass. For further differentiation of the mass an abdominal computed tomography was performed. This scan detected an exophytic, thick-walled, cavity-forming, whimsical tumor in the lower abdomen of $7 \times 10 \times 10 \mathrm{~cm}$. The tumor originated from the small intestine and was filled with oral contrast from the terminal small bowel. It compressed the bladder and bowel surrounding the lesion. However, there seemed to exist no invasive growth into the environment (fig. 1). In our multidisciplinary team we decided to perform an explorative laparotomy, which showed a large solid tumor originating in the small bowel, $180 \mathrm{~cm}$ proximal to the ileocecal valve, on the antimesenteric side. There were some adhesions to the greater omentum, but there was no invasion into surrounding structures. On palpation there were no enlarged lymph nodes. There were no other lesions in the abdominal cavity. En bloc resection of the tumor and $15 \mathrm{~cm}$ of the small intestine with a side-to-side anastomosis was performed (fig. 2). The postoperative course was uneventful and the patient could be discharged after 4 days.

On pathological examination the outer aspect of the tumor was smooth-walled with a good vascular support and partly multinodular (fig. 3). It concerned a spherical cystic lesion filled with blood clots which was connected to the small intestine (fig. 4). The diameter of the lesion was $11.0 \mathrm{~cm}$. On microscopic examination radical resection was confirmed. 
Timmers et al.: Survival after Resection of a Primary Malignant Melanoma of the Small Intestine in a Young Patient: Report of a Case

Immunohistochemical stains showed that the neoplastic cells were strongly reactive for MelanAF, S100 and HMB45 (fig. 5, fig. 6). After the histopathological examination, a diagnosis of malignant melanoma was made. Supplementary molecular genetic research showed no mutation in NRAS in codons 12, 13 and 61, no mutation in exons 9, 11, 13 and 17 (c-kit) and no mutation in BRAF in codon 600.

A total body positron emission tomography (PET) scan was negative for hypermetabolic activity and also MRI of the brain and vertebral spine was negative for tumor. A clinically extensive investigation of the skin, anus, nose and eyes by a dermatologist, an otolaryngologist and an ophthalmologist did not detect a primary lesion site.

One year after discharge a PET-CT scan was performed, which was negative for any recurrent disease or metastasis. The patient continued to be in a healthy condition during his outpatient department follow-up.

\section{Discussion}

Malignant melanoma of the skin or epithelia is known to metastasize to the intestines. Primary melanomas of the GI tract, however, are a very rare entity. They are rarely diagnosed at an early stage, tend to be more aggressive and are associated with a poor prognosis [5]. The common feature of all melanomas is the cell of origin, the melanocyte. Melanocytes are pigmented dendritic-like cells located in various anatomic sites. These sites include the base of the epidermis, the eye, and epithelia of the nasal cavity, oropharynx, anus, vagina and urinary tract. In addition to these sites, melanocytes have been demonstrated in Meckel's diverticulum by immunoperoxidase studies $[9,10]$. Normally the small bowel and colon contain no melanocytes. Melanomas of the small bowel are thought to originate from melanoblastic cells of the neural crest, which migrate to the distal ileum through the umbilicalmesenteric canal $[9,11]$. In the gut, neural crest cells differentiate into amine precursor uptake and decarboxylation (APUD) cells, which can undergo neoplastic transformation and produce tumors such as carcinoids or gastrinomas. Melanomas may potentially originate from APUD cells, although they do not, unlike the usual APUDomas, produce any hormones. According to the APUD theory, the ileum, which represents the distal end of the umbilicalmesenteric canal, should be the most common site of primary malignant melanoma within the small intestine [12].

A clear distinction between primary intestinal melanoma and intestinal metastatic deposits can be difficult when considering histopathological features alone [13]. Bender et al. [14] defined four different types of metastatic melanoma of the small bowel: cavitary, infiltrating, exoenteric and polypoid. These four types are not always distinct. In addition they may be either pigmented or amelanotic. Histological features of metastasized intestinal melanoma that develop after spontaneous regression of primary cutaneous melanoma include lymphocytic infiltration of the dermis with melanophages, vascular proliferation and reparative fibrosis [6].

Clinically, melanomas of the GI tract can cause a wide range of symptoms, depending on their location and size. Nonspecific symptoms such as weight loss, GI bleeding, anemia and signs of GI obstruction can occur. When after investigation a tumor of the small intestine is suspected, primary melanoma should be included in the differential diagnosis.

Clinical distinction between a primary GI mucosal melanoma and a melanoma metastatic to the GI tract from an unknown or regressed cutaneous primary may also be difficult [5]. Moreover, some authors deny the existence of primary melanomas in the GI tract. They postulate that a primary tumor regresses before the occurrence of metastases or is too small 
Timmers et al.: Survival after Resection of a Primary Malignant Melanoma of the Small Intestine in a Young Patient: Report of a Case

to be identified $[3,15]$. We together with other authors claim that primary small bowel melanomas do exist $[2,4,16]$. A primary GI mucosal melanoma is suggested if the patient has no obvious primary cutaneous melanoma or has an isolated GI lesion without other extraintestinal metastases [5, 6, 15, 17-19]. Blecker et al. [20] propose the following criteria for the diagnosis of a primary melanoma of small bowel: (1) presence of a solitary mucosal lesion in the intestinal epithelium, (2) absence of melanoma or atypical melanocytic lesions of the skin, and (3) presence of intramucosal melanocytic lesions in the overlying or adjacent intestinal epithelium. According to Sachs et al. [2] a diagnosis should be contingent on the presence of a solitary lesion, no metastatic deposits other than those in the regional lymph nodes, and disease-free survival of at least 12 months after diagnosis.

We performed a search of the literature using Ovid MEDLINE with the subject headings 'melanoma' and 'gastrointestinal tract' and the key word 'unknown primary' to search for all case reports and reviews published on malignant melanoma metastatic to the GI tract, subdivided into small bowel/intestine. References cited in case series and case reports were hand searched to obtain all related relevant articles. Similar searches were performed using PubMed and EMBASE. Twenty-four different case reports, including ours, have been published in the last three decades [3, 4, 7-9, 12, 21-37]. In most of these cases, however, follow-up is short or not mentioned and therefore they do not meet the criteria as proposed by Sachs et al. [2].

In 2005 Krüger et al. [12] reviewed 18 cases of primary malignant melanoma of the small bowel. In 5 of these cases a follow-up of 12 months or longer is reported; 2 of these had tumor recurrence. Whether the often early recurrence reflects a poor prognosis of primary melanoma of the small intestine or a sign of other primary origin remains unclear.

The cases described show a wide range of age at time of diagnosis with the highest incidence above the age of 40 . The patient presented in this case was 25 years of age at the time of diagnosis and is, to our knowledge, the youngest patient described.

In conclusion, we report the case of a young patient in whom a large solitary malignant melanoma of the small intestine was diagnosed. He underwent radical resection of the tumor. Histopathological examination confirmed that the tumor was a malignant melanoma. Further examination (clinical, MRI, CT and PET scan) did not detect a primary lesion site or lymph nodes suspicious for metastasis. At 1-year follow-up the patient was disease-free. Thus our case is consistent with the diagnosis of primary intestinal melanoma.

\section{References}

$\checkmark 1$ Chang AE, Karnell LH, Menck HR: The National Cancer Data Base report on cutaneous and noncutaneous melanoma: a summary of 84,836 cases from the past decade. The American College of Surgeons Commission on Cancer and the American Cancer Society. Cancer 1998;83:1664-1678.

2 Sachs DL, Lowe L, Chang AE, Carson E, Johnson TM: Do primary small intestinal melanomas exist? Report of a case. J Am Acad Dermatol 1999;41:1042-1044.

-3 Elsayed AM, Albahra M, Nzeako UC, Sobin LH: Malignant melanomas in the small intestine: a study of 103 patients. Am J Gastroenterol 1996;91:1001-1006.

-4 Atmatzidis KS, Pavlidis TE, Papaziogas BT, Papaziogas TB: Primary malignant melanoma of the small intestine: report of a case. Surg Today 2002;32:831-833.

5 Schuchter LM, Green R, Fraker D: Primary and metastatic diseases in malignant melanoma of the gastrointestinal tract. Curr Opin Oncol 2000;12:181-185.

-6 Poggi SH, Madison JF, Hwu WJ, Bayar S, Salem RR: Colonic melanoma, primary or regressed primary. J Clin Gastroenterol 2000;30:441-444.

7 Kadivar TF, Vanek VW, Krishnan EU: Primary malignant melanoma of the small bowel: a case study. Am Surg 1992;58:418-422.

-8 Manouras A, Genetzakis M, Lagoudianakis E, et al: Malignant gastrointestinal melanomas of unknown origin: should it be considered primary? World J Gastroenterol 2007;13:4027-4029. 


\begin{tabular}{l|l}
\hline Case Rep Gastroenterol 2013;7:251-260 \\
\hline DOI: 10.1159/000352017 & $\begin{array}{l}\text { C 2013 S. Karger AG, Basel } \\
\text { www.karger.com/crg }\end{array}$ \\
\hline
\end{tabular}

Timmers et al.: Survival after Resection of a Primary Malignant Melanoma of the Small Intestine in a Young Patient: Report of a Case

9 Amar A, Jougon J, Edouard A, Laban P, Marry JP, Hillion G: Primary malignant melanoma of the small intestine (in French). Gastroenterol Clin Biol 1992;16:365-367.

10 Bloch T, Tejada E, Brodhecker C: Malignant melanoma in Meckel's diverticulum. Am J Clin Pathol 1986;86: 231-234.

11 DasGupta TK, Brasfield RD: Metastatic melanoma of the gastrointestinal tract. Arch Surg 1964;88:969-973.

12 Krüger S, Noack F, Blöchle C, Feller AC: Primary malignant melanoma of the small bowel. A case report and review of the literature. Tumori 2005;91:73-76.

13 Lens M, Bataille V, Krivokapic Z: Melanoma of the small intestine. Lancet Oncol 2009;10:516-521.

14 Bender GN, Maglinte DD, McLarney JH, Rex D, Kelvin FM: Malignant melanoma: patterns of metastasis to the small bowel, reliability of imaging studies, and clinical relevance. Am J Gastroenterol 2001;96:2392-2400.

15 DeMatos P, Wolfe WG, Shea CR, Prieto VG, Seigler HF: Primary malignant melanoma of the esophagus. J Surg Oncol 1997;66:201-206.

16 Patti R, Cacciatori M, Guergio G, Territo V, Di Vita G: Intestinal melanoma: a broad spectrum of clinical presentation. Int J Surg Case Rep 2012;3:395-398.

17 Haga Y, Iwanaga Y, Matsumura F, et al: Curatively resected primary malignant melanoma of the esophagus: report of a case. Surg Today 1993;23:820-824.

18 Stranks GJ, Mathai JT, Rowe-Jones DC: Primary malignant melanoma of the oesophagus: case report and review of surgical pathology. Gut 1991;32:828-830.

19 Joob AW, Haines GK III, Kies MS, Shields TW: Primary malignant melanoma of the esophagus. Ann Thorac Surg 1995;60:217-222.

-20 Blecker D, Abraham S, Furth EE, Kochman ML: Melanoma in the gastrointestinal tract. Am J Gastroenterol 1999;94:3427-3433.

21 Mittal VK, Bodzin JH: Primary malignant tumors of the small bowel. Am J Surg 1980;140:396-399.

22 Krausz MM, Ariel I, Behar AJ: Primary malignant melanoma of the small intestine and the APUD cell concept. J Surg Oncol 1978;10:283-288.

23 Raymond AR, Rorat E, Goldstein D, Lubat E, Strutynsky N, Gelb A: An unusual case of malignant melanoma of the small intestine. Am J Gastroenterol 1984;79:689-692.

24 Tabaie HA, Citta RJ, Gallo L, Biondi RJ, Meoli FG, Silverman D: Primary malignant melanoma of the small intestine: report of a case and discussion of the APUD cell concept. J Am Osteopath Assoc 1984;83:374-377.

25 Yashige H, Horishi M, Suyama Y, et al: A primary malignant melanoma of the small intestine. Gan No Rinsho 1990;36:955-958.

26 Ramadan E, Mittelman M, Kyzer S, Chaimoff C: Unusual presentation of malignant melanoma of the small intestine. Harefuah 1992;122:634-635.

27 Lizasoain UJ, Gonzalez SAP, De Castro CJ, et al: Melanoma of the small intestine and adenocarcinoma of the colon. Gastroenterol Hepatol 1995;18:323-325.

28 Wade TP, Goodwin MN, Countryman DM, Johnson FE: Small bowel melanoma: extended survival with surgical management. Eur J Surg Oncol 1995;21:90-91.

29 Christova S, Meinhard K, Mihailov I, Alexiev B: Three cases of primary malignant melanoma of the alimentary tract. Gen Diagn Pathol 1996;142:63-67.

-30 Kogire M, Yanagibashi K, Shimogou T, et al: Intussusception caused by primary malignant melanoma of the small intestine. Nihon Geka Hokan 1996;65:54-59.

-31 Sorensen YA, Larsen LB: Malignant melanoma in the small intestine. Ugeskr Laeger 1998;160:1480-1481.

-32 Khoshrowshahi E, Horvath W: Primary malignant melanoma of the small intestine: a case report. Röntgenpraxis 2002;54:220-223.

-33 Yanar H, Coskun H, Aksoy S, Tekinel M: Malignant melanoma of the small bowel as a cause of occult intestinal bleeding: case report. Ulus Travma Derg 2003;9:82-84.

-34 Iijima S, Oka K, Sasaki M, et al: Primary jejunal malignant melanoma first noticed because of the presence of parotid lymph node metastasis. J Am Acad Dermatol 2003;49:319-323.

-35 Kim W, Baek JM, Suh YJ, Jeon HM, Kim JA: Ileal malignant melanoma presenting as a mass with aneurysmal dilatation: a case report. J Korean Med Sci 2004;19:297-301.

-36 Crippa S, Bovo G, Romano F, Mussi C, Uggeri F: Melanoma metastatic to the gallbladder and small bowel: report of a case and review of the literature. Melanoma Res 2004;14:427-430.

-37 Guraya SY, Al Naami M, Al Tuwaijri T, Arafah MM: Malignant melanoma of the small bowel with unknown primary: a case report. J Ayub Med Coll Abbottabad 2007;19:63-65. 


\begin{tabular}{|c|c|c|}
\hline \multirow{3}{*}{$\begin{array}{r}\text { Case Reports in } \\
\text { Gastroenterology }\end{array}$} & \multirow{2}{*}{\multicolumn{2}{|c|}{ Case Rep Gastroenterol 2013;7:251-260 }} \\
\hline & & \\
\hline & DOI: $10.1159 / 000352017$ & $\begin{array}{l}\text { (c) } 2013 \text { S. Karger AG, Basel } \\
\text { www.karger.com/crg }\end{array}$ \\
\hline
\end{tabular}
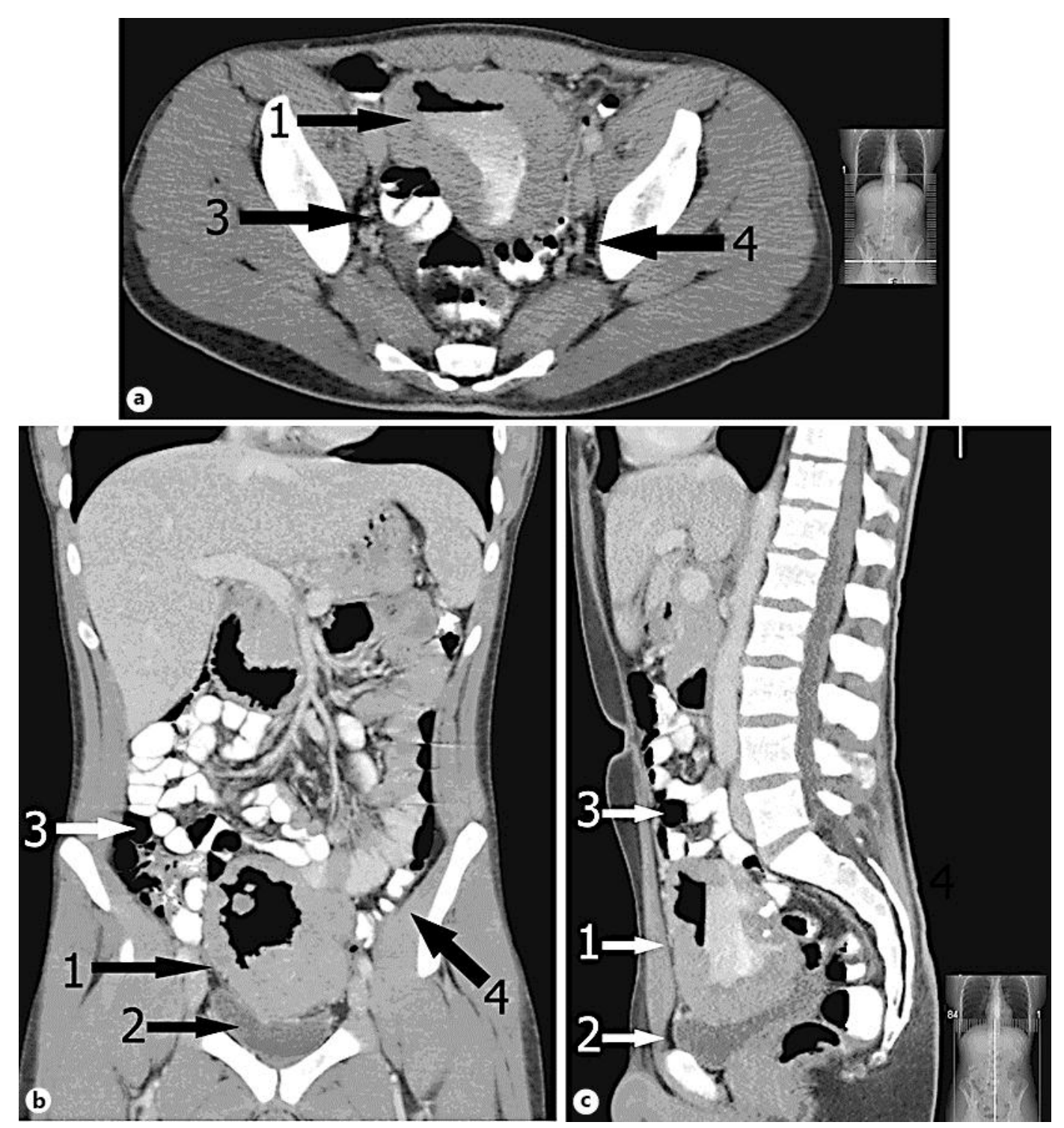

Fig. 1. a Axial abdominal CT image. b Coronal CT image. c Sagittal CT image. On abdominal CT scan an exophytic, thick-walled, cavity-forming, whimsical tumor in the lower abdomen (1) of $7 \times 10 \times 10 \mathrm{~cm}$ was detected. The tumor originated from the small intestine and filled itself with oral contrast from the terminal small bowel. The tumor compressed the bladder (2) and bowel (3: small intestine; 4: colon) surrounding the lesion. However, there seemed to exist no invasive growth into the environment. 


\begin{tabular}{ll|l} 
Case Reports in & \multicolumn{2}{l}{ Case Rep Gastroenterol 2013;7:251-260 } \\
\cline { 2 - 3 } Gastroenterology & $\begin{array}{l}\text { DO 2013 S. Karger AG, Basel } \\
\text { www.karger.com/crg }\end{array}$ \\
\hline $\begin{array}{l}\text { Timmers et al.: Survival after Resection of a Primary Malignant Melanoma of the Small } \\
\text { Intestine in a Young Patient: Report of a Case }\end{array}$
\end{tabular}

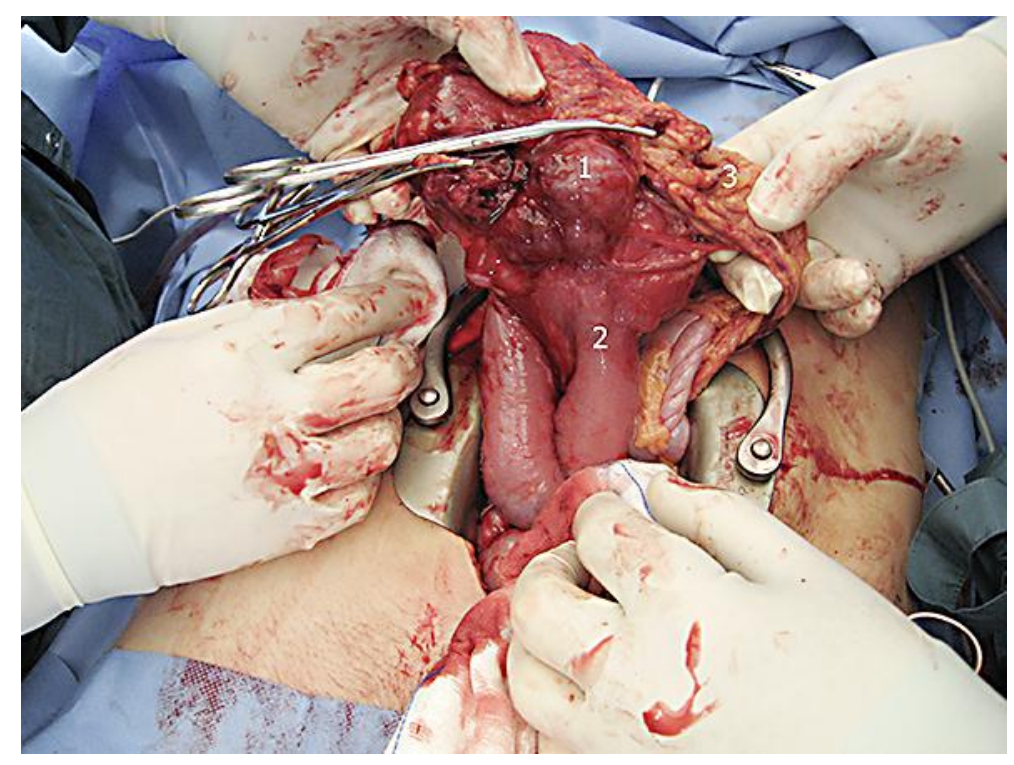

Fig. 2. Location of the tumor with a very close relation to the small intestine. However, it did not invade nearby structures. 1 = Tumor cavity; 2 = small intestine; 3 = small intestine mesentery.

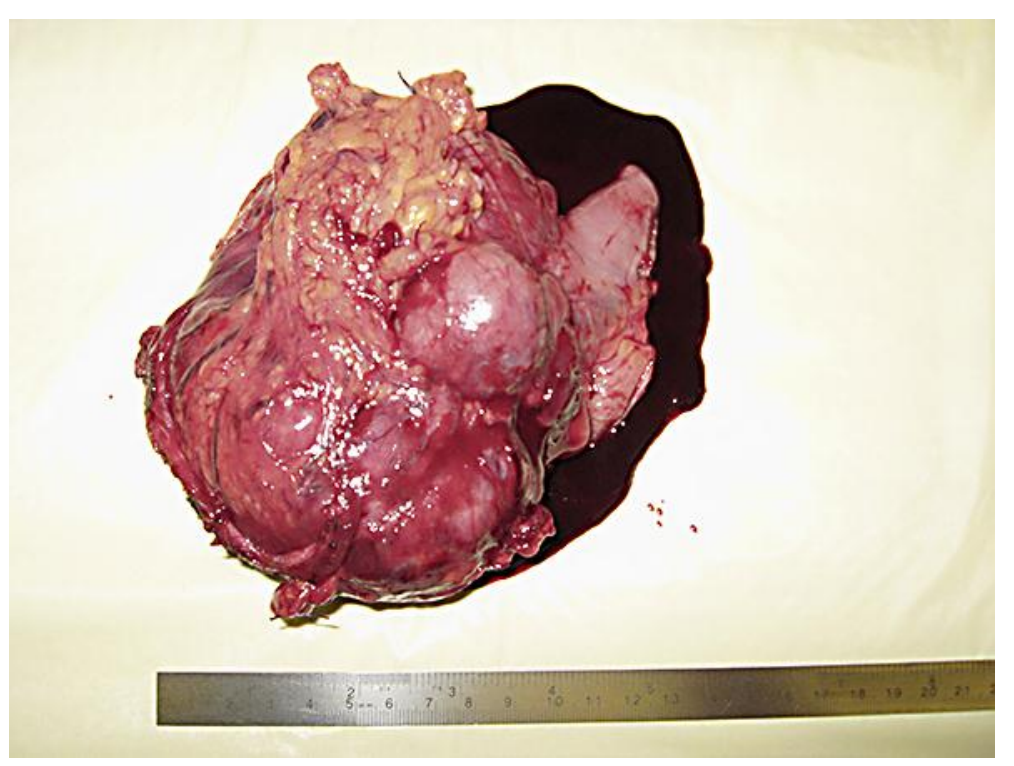

Fig. 3. Complete resection of the tumor. The tumor seemed smooth-walled with a good vascular support and partly multinodular aspect. 


\begin{tabular}{ll|l} 
Case Reports in & \multicolumn{2}{l}{ Case Rep Gastroenterol 2013;7:251-260 } \\
\cline { 2 - 3 } Gastroenterology & $\begin{array}{l}\text { DO 2013 S. Karger AG, Basel } \\
\text { www.karger.com/crg }\end{array}$ \\
\hline $\begin{array}{l}\text { Timmers et al.: Survival after Resection of a Primary Malignant Melanoma of the Small } \\
\text { Intestine in a Young Patient: Report of a Case }\end{array}$
\end{tabular}

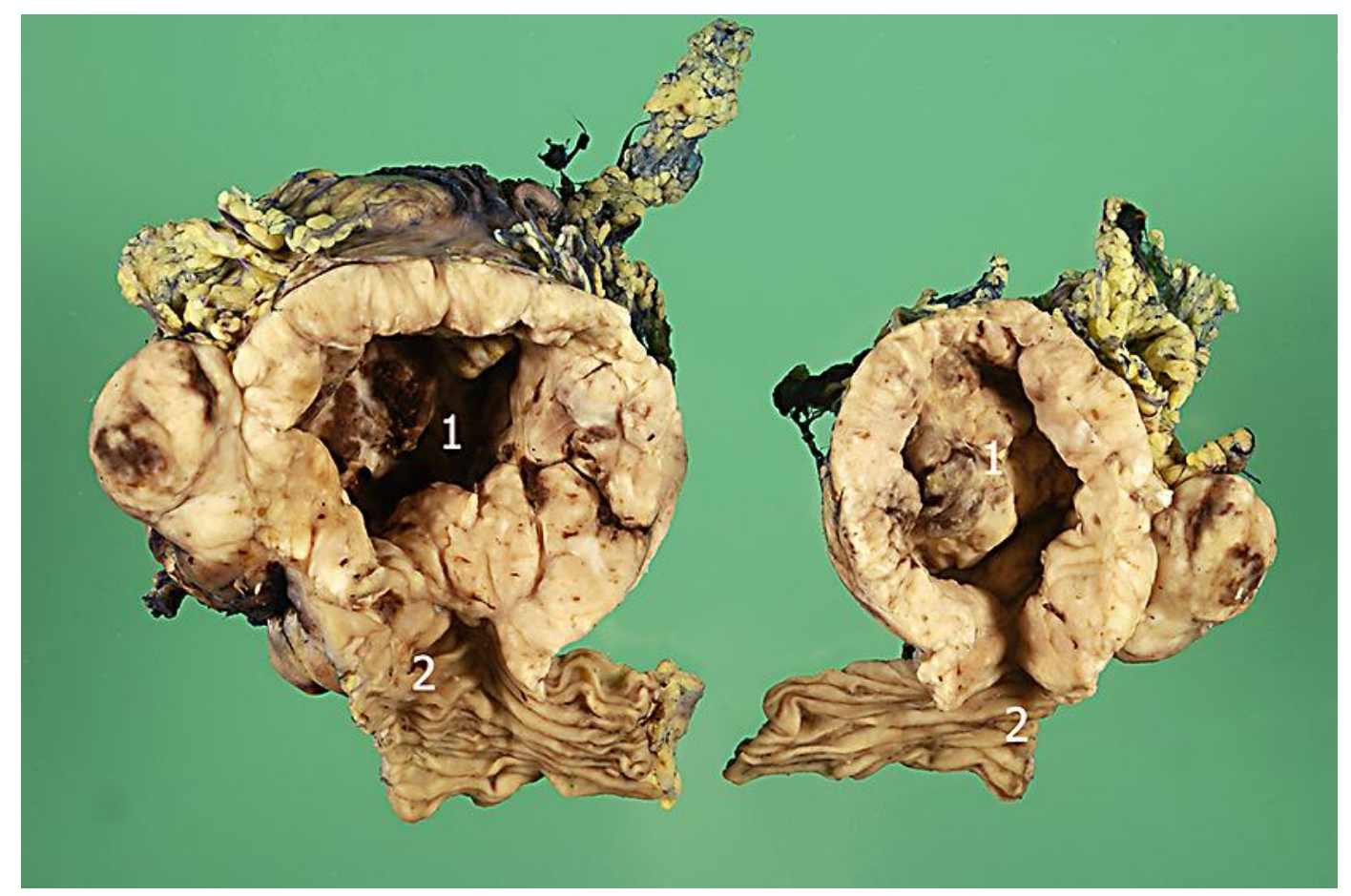

Fig. 4. Macroscopic image of the tumor cut in half, prepared in formaldehyde for pathological examination. 1 = Tumor cavity; 2 = small intestine with opening to the tumor cavity. 


\begin{tabular}{ll|l} 
Case Reports in & \multicolumn{2}{l}{ Case Rep Gastroenterol 2013;7:251-260 } \\
\cline { 2 - 3 } Gastroenterology & DOI: 10.1159/000352017 & $\begin{array}{l}\text { ○ 2013 S. Karger AG, Basel } \\
\text { www.karger.com/crg }\end{array}$ \\
\cline { 2 - 2 } & $\begin{array}{l}\text { Timmers et al.: Survival after Resection of a Primary Malignant Melanoma of the Small } \\
\text { Intestine in a Young Patient: Report of a Case }\end{array}$
\end{tabular}

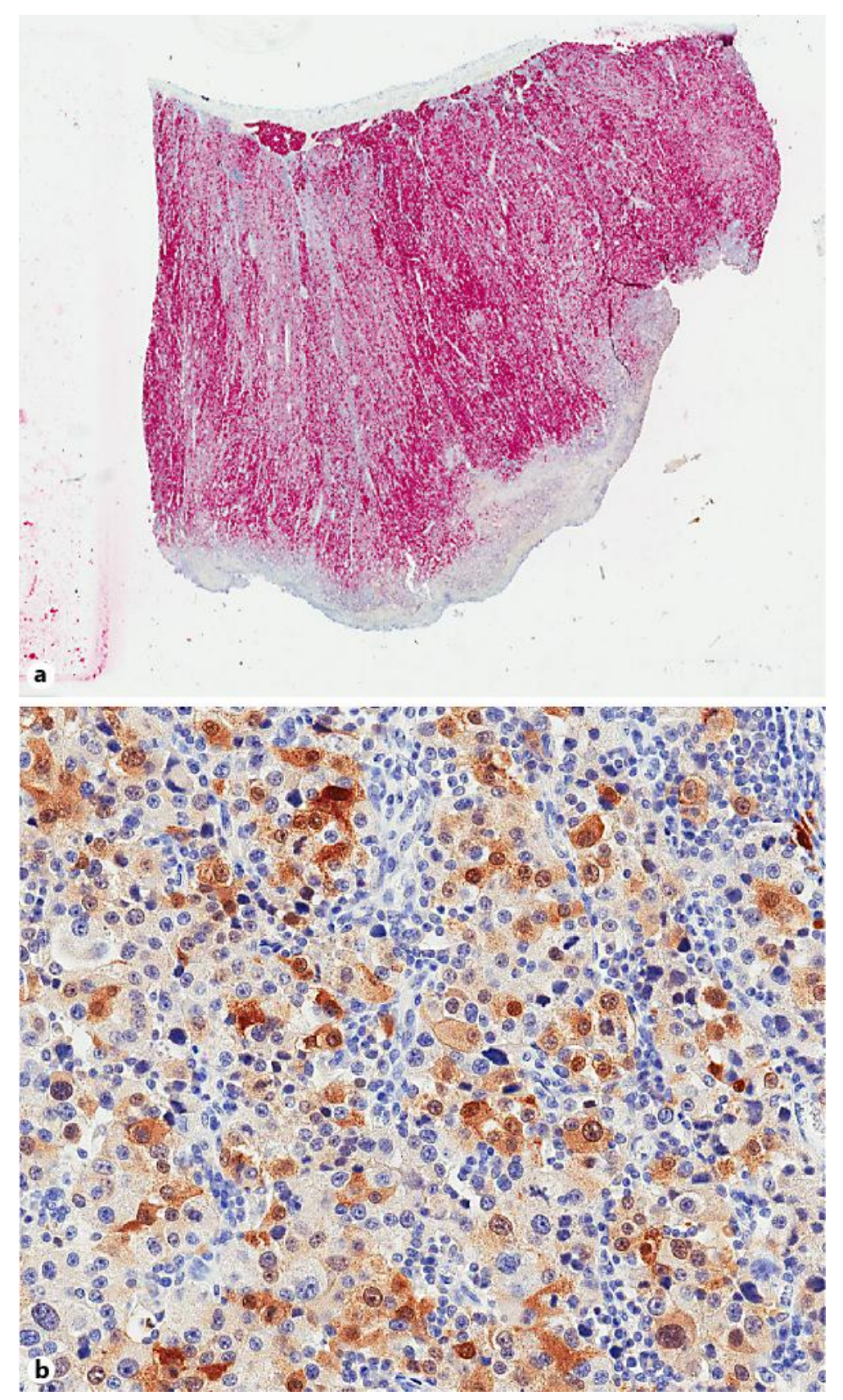

Fig. 5. Immunohistochemical stains showed that the neoplastic cells were strongly reactive for MelanAF (a) and S100 (b). 


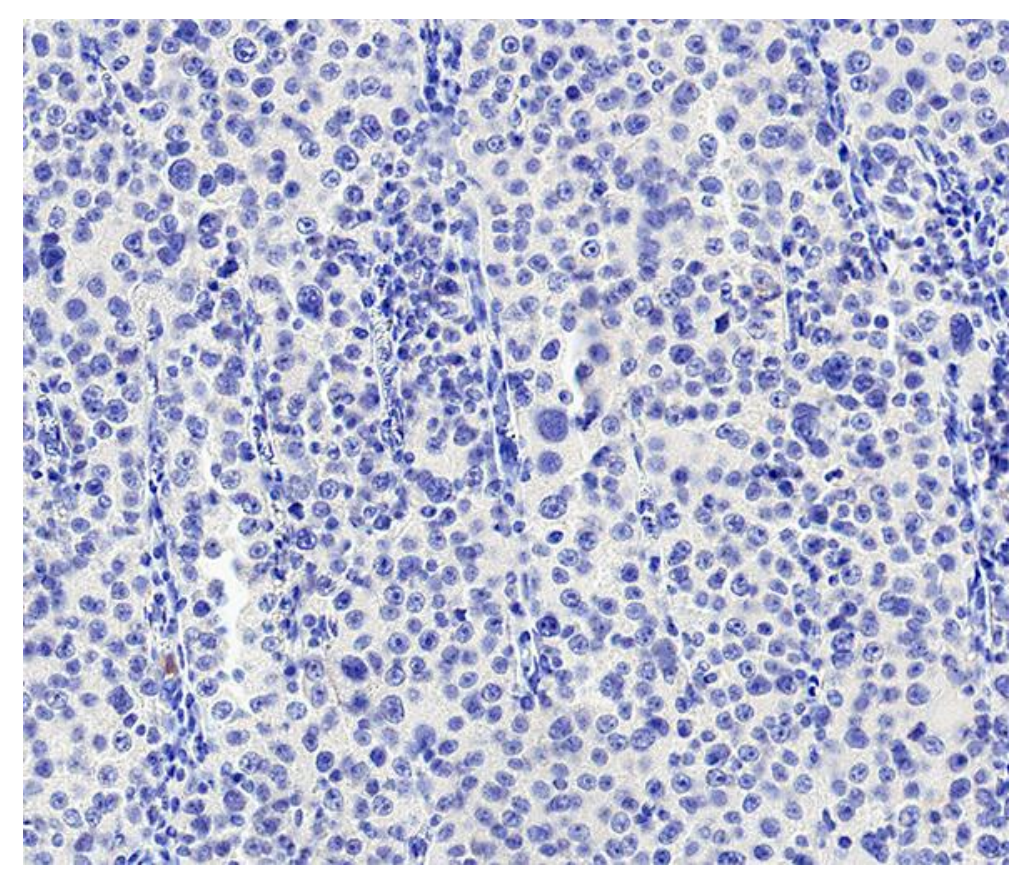

Fig. 6. Immunohistochemical stains showed that the neoplastic cells were strongly negative for CD10. 